\title{
Management of liquid swine manure: impact on mineral nitrogen dynamics and corn yield ${ }^{1}$
}

\author{
Claudir José Basso², Marlo Adriano Bison Pinto 3 , \\ Rogério Gonzatto ${ }^{4}$, Stefen Barbosa Pujol ${ }^{4}$, Fernanda Marcolan de Souza ${ }^{2}$
}

\section{ABSTRACT}

The agronomic efficiency of liquid swine manure (LSM) depends on the use of strategies to mitigate nitrogen $(\mathrm{N})$ losses after its application to the soil, and thus preserve its fertilizing potential. In order to evaluate the injection of LSM into the soil and the addition of a nitrification inhibitor, as ways to increase its efficiency as a $\mathrm{N}$ source to the corn crop in the no-tillage system, an experiment was carried out under an Aluminofferic Red Latosol. The used treatments were: one control, surface application (total area) of LSM, injection of LSM in furrows, surface application (total area) of LSM + dicyandiamide (DCD), injection of LSM + DCD in furrows, and mineral fertilization. The mineral $\mathrm{N}$ in the soil and number of rows per ear, number of grains per row, 1,000-grain mass and grain yield for corn were evaluated. One day after the application of the treatments, the recovery of the mineral $\mathrm{N}$ in the soil with the injection of LSM exceeded by $10 \mathrm{~kg} \mathrm{ha}^{-1}$ that observed with the superficial application. With DCD, the recovery of anionic forms $\left(\mathrm{NO}_{2}\right.$ and $\mathrm{NO}_{3}^{-}$) in the soil was lower in the first 20 days after the application, with the change in the $\mathrm{N}$ dynamics caused by DCD resulting in a higher content of mineral $\mathrm{N}$ at 30 days after sowing. The transformation rate for the anionic forms of mineral $\mathrm{N}$ in the soil is reduced with the addition of DCD. The injection of LSM with DCD does not differ from mineral fertilization, in terms of corn grain yield.

KEYWORDS: Zea mays L., nitrification inhibitor, organic fertilization.

\section{INTRODUCTION}

Organic fertilization is a promising tool, due to the high cost of the synthetic fertilizers used in agricultural crops. In this context, the use of liquid swine manure (LSM) may be an important alternative

\section{RESUMO}

Manejo de dejeto líquido suíno: impacto sobre a dinâmica de nitrogênio mineral e produtividade de milho

A eficiência agronômica do dejeto líquido de suínos (DLS) depende do emprego de estratégias para mitigar as perdas de nitrogênio $(\mathrm{N})$ após sua aplicação no solo, e assim preservar seu potencial fertilizante. A fim de avaliar a injeção de DLS no solo e a adição de inibidor de nitrificação, como formas de aumentar sua eficiência como fonte de $\mathrm{N}$ à cultura do milho no sistema plantio direto, foi conduzido um experimento sob Latossolo Vermelho Aluminoférrico. Os tratamentos utilizados foram: uma testemunha, aplicação em superfície (área total) de DLS, injeção de DLS em sulcos, aplicação em superfície (área total) de DLS + dicianodiamida (DCD), injeção de DLS + DCD em sulcos e adubação mineral. Avaliaram-se o $\mathrm{N}$ mineral no solo e o número de fileiras por espiga, número de grãos por fileira, massa de mil grãos e a produtividade de milho. Um dia após a aplicação dos tratamentos, a recuperação de $\mathrm{N}$ mineral no solo com a injeção de DLS superou em $10 \mathrm{~kg} \mathrm{ha}^{-1}$ o observado com a aplicação superficial. Com $\mathrm{DCD}$, a recuperação de formas aniônicas $\left(\mathrm{NO}_{2}^{-} \mathrm{e} \mathrm{NO}_{3}^{-}\right)$no solo foi menor nos primeiros 20 dias após a aplicação, sendo que a alteração na dinâmica do N provocada por DCD resultou em maior conteúdo de $\mathrm{N}$ mineral aos 30 dias após a semeadura. A velocidade de transformação para as formas aniônicas de $\mathrm{N}$ mineral no solo é reduzida com a adição de DCD. A injeção de DLS com DCD não difere da adubação mineral, quanto à produtividade de grãos de milho.

PALAVRAS-CHAVE: Zea mays L., inibidor de nitrificação, adubação orgânica.

source of nitrogen $(\mathrm{N})$ fertilization for commercial crops, because, in addition to totally or partially replacing mineral fertilization, it enables a more efficient use of this residue (Seidel et al. 2010).

Considering that the availability of LSM nutrients is affected by intrinsic factors and by

\footnotetext{
${ }^{1}$ Received: Aug. 02, 2020. Accepted: Oct. 26, 2020. Published: Dec. 02, 2020. DOI: 10.1590/1983-40632020v5064790.
}

${ }^{2}$ Universidade Federal de Santa Maria, Departamento de Ciências Agronômicas e Ambientais, Frederico Westphalen, RS, Brasil.

E-mail/ORCID: claudirbasso@gmail.com/0000-0002-3013-5702, fernanda22ms@gmail.com/0000-0002-4791-1325.

${ }^{3}$ Instituto Federal Farroupilha, Departamento de Recursos Naturais, Santo Augusto, RS, Brasil.

E-mail/ORCID: marlo.pinto@iffarroupilha.edu.br/0000-0003-1567-8490.

${ }^{4}$ Universidade Federal de Santa Maria, Centro de Ciências Rurais, Departamento de Solos, Santa Maria, RS, Brasil.

E-mail/ORCID: rogonzatto@gmail.com/0000-0001-8376-3684,pujolstefen@gmail.com/0000-0003-3530-7814. 
soil and climate conditions (Ceretta et al. 2010), improving the synchronism between availability and demand for the crop is essential to obtain a response in yield (Angers et al. 2010).

The $\mathrm{N}$ present in LSM is found mostly in the ammoniacal form, approximately $60 \%$, the remainder being represented by the organic form (Aita et al. 2014). With immediate availability for agricultural crops, ammoniacal $\mathrm{N}$ is also subjected to losses, whether through runoff (Ceretta et al. 2005), ammonia volatilization $\left(\mathrm{NH}_{3}\right)$ (Aita et al. 2014), leaching as nitrite $\left(\mathrm{NO}_{2}^{-}\right)$and nitrate $\left(\mathrm{NO}_{3}^{-}\right)$after the nitrification process (Dell et al. 2012), or through the emission of nitrous oxide $\left(\mathrm{N}_{2} \mathrm{O}\right)$ and molecular nitrogen $\left(\mathrm{N}_{2}\right)$ during denitrification (Aita et al. 2015). In this scenario, finding strategies to mitigate $\mathrm{N}$ losses after applying LSM means preserving its fertilizing value as a source of $\mathrm{N}$ to crops.

The increase in the agronomic efficiency of LSM depends on the use of technologies that minimize $\mathrm{N}$ losses to the environment, ensuring a greater availability for absorption by plants. In this sense, the injection of LSM into the soil and the use of nitrification inhibitors, such as dicyandiamide (DCD), are promising technologies and have been showing a positive potential (Aita et al. 2014, Oliveira et al. 2020).

The injection of LSM into the soil may reduce $\mathrm{N}$ losses due to $\mathrm{NH}_{3}$ volatilization by up to $90 \%$ (Gonzatto et al. 2016), while the use of DCD delays the ammoniacal $\mathrm{N}$ nitrification, reducing the $\mathrm{NO}_{3}^{-}$ leaching by up to $77 \%$ (Vallejo et al. 2005), and up to $80 \%$ the $\mathrm{N}_{2} \mathrm{O}$ emission (Gonzatto et al. 2017). In addition, some studies show that the combined use of the two strategies (injection into the soil and addition of DCD nitrification inhibitor) favors the absorption of $\mathrm{N}$ by crops (Vallejo et al. 2005, Gonzatto et al. 2016). However, there are few studies about the effect of these strategies on the dynamics of mineral $\mathrm{N}$ applied via LSM and the impact on corn grain yield, since this practice is effective for the crop (Seidel et al. 2010).

In this context, this study aimed to evaluate the effect of LSM injection into the soil and the use of DCD nitrification inhibitor on the dynamics of mineral $\mathrm{N}$ in the soil and the yield of corn grains in the no-tillage system.

\section{MATERIAL AND METHODS}

The experiments were conducted during the 2014/2015 (1st year) and 2016 (2nd year) agricultural years, in an experimental area located near the campus of the Universidade Federal de Santa Maria, in Frederico Westphalen, Rio Grande do Sul state, Brazil (27'23'58'S, 53'25'22'W and altitude of $594 \mathrm{~m}$ ). The soil in the area is classified as a typical Aluminofferic Red Latosol (Embrapa 2013), cultivated for 12 years under no-tillage and with the following chemical and physical attributes (0-0.10 m layer): $768.3 \mathrm{~g} \mathrm{~kg}^{-1}$ of clay; $77.3 \mathrm{~g} \mathrm{~kg}^{-1}$ of silt; $154.6 \mathrm{~g} \mathrm{~kg}^{-1}$ of sand; $2.98 \mathrm{~g} \mathrm{dm}^{-3}$ of organic matter; 5.0 of $\mathrm{pH}\left(\mathrm{H}_{2} \mathrm{O}\right) ; 7 \mathrm{mg} \mathrm{dm}^{-3}$ of $\mathrm{P}$ (Mehlich-1); $93.68 \mathrm{mg} \mathrm{dm}^{-3}$ of $\mathrm{K}$ (Mehlich-1); and density of $1.35 \mathrm{~g} \mathrm{~cm}^{-3}$.

The climate of the region, according to the Köppen classification, is Cfa humid subtropical, with an average annual temperature of $19.1{ }^{\circ} \mathrm{C}$ and maximum and minimum temperatures of $38{ }^{\circ} \mathrm{C}$ and $0{ }^{\circ} \mathrm{C}$, respectively (Alvares et al. 2013). The data of pluviometric precipitation and average air temperature observed during the conduction of the experiment (Figure 1) were obtained from an automatic meteorological station located about $700 \mathrm{~m}$ away from the experiment area.

The experimental design was randomized blocks, with four replications. The treatments consisted of one control (Ctrl), surface application (total area) of LSM (Sur), injection of LSM into the soil in furrows (Inj), surface application (total area) of LSM + DCD (Sur + DCD), injection of $\mathrm{LSM}+\mathrm{DCD}$ into the soil in furrows (Inj + DCD), and mineral fertilization. The corn hybrid DKB 240 VT PRO 2 (super-early cycle) was sown with a tractorized seeder one day after the application of the LSM, in rows spaced at $0.7 \mathrm{~m}$, with a population of 80.000 seeds ha ${ }^{-1}$.

Fertilizers, both mineral and organic, followed the recommendation for corn with an expected yield of $6,000 \mathrm{~kg} \mathrm{ha}^{-1}$ (CQFS 2004), based on the soil analysis of the area. Thus, at the time of sowing with mineral fertilization, $20 \mathrm{~kg} \mathrm{ha}^{-1}$ of $\mathrm{N}$ were applied in the form of urea at the base and in both years, $50 \mathrm{~kg} \mathrm{ha}^{-1}$ of $\mathrm{K}_{2} \mathrm{O}$ in the form of potassium chloride in the two years of the experiment, and $75 \mathrm{~kg} \mathrm{ha}^{-1}$ and $105 \mathrm{~kg} \mathrm{ha}^{-1}$ of $\mathrm{P}_{2} \mathrm{O}_{5}$ in the first and second years, respectively, in the form of triple superphosphate. In addition to the $\mathrm{N}$ used at the sowing time, another application of urea was broadcasted when the crop was in the stage $\mathrm{V} 4$, applying $92.2 \mathrm{~kg} \mathrm{ha}^{-1}$ of $\mathrm{N}$ on January 15, 2015 (29 days after sowing) in the 1st year and February 11, 2016 (33 days after sowing) in the 2 nd year. 

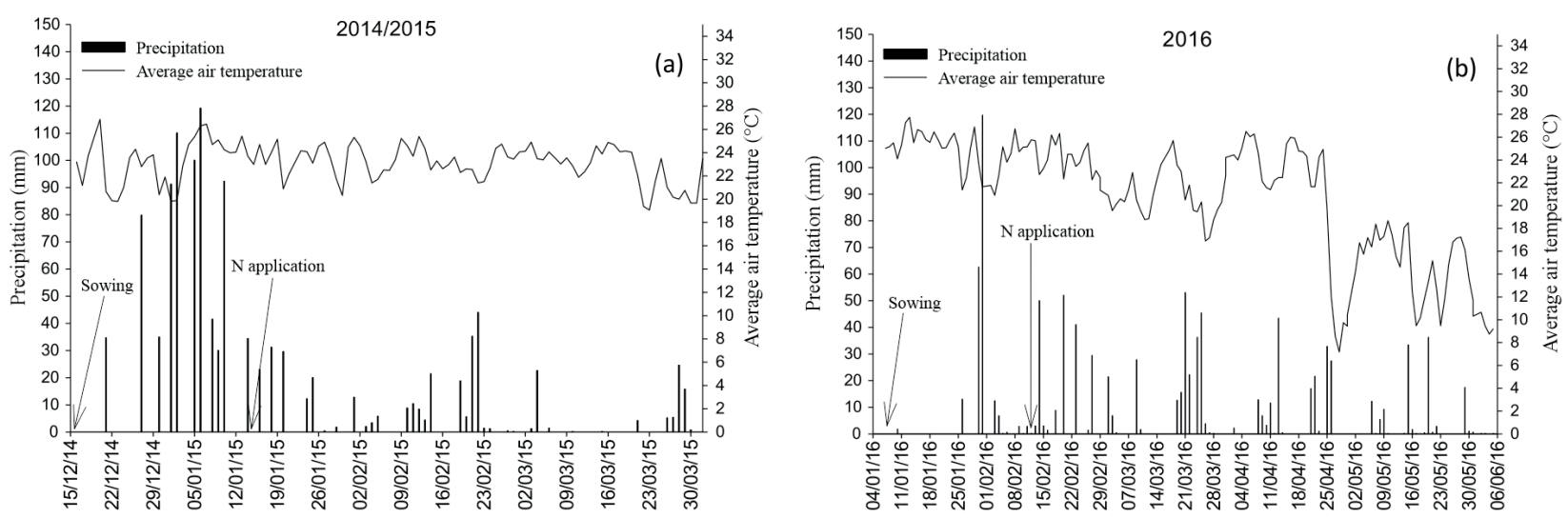

Figure 1. Precipitation (mm) and average air temperature $\left({ }^{\circ} \mathrm{C}\right)$, every seven days, in the 2014/2015 (a) and 2016 (b) crop seasons.

The amounts of LSM coming from animals in the finishing phase (Table 1) were equal to 75 and $46 \mathrm{~m}^{3} \mathrm{ha}^{-1}$, in the 1 st and 2 nd years, respectively. LSM was applied in a single moment, on December 16, 2014 (1st year) and January 07, 2016 (2nd year), preceding the corn sowing in one day, with the treatments allocated in plots of $36 \mathrm{~m}^{2}$ and useful area of $16 \mathrm{~m}^{2}$.

The cover application of LSM (total area) was carried out using watering cans and, for the injection of the liquid organic fertilizer, a spreader with incorporator was used. The metal tank of the equipment had a capacity of 4,000 L. The injection began after the hydraulic piston was activated, being responsible for inserting a guillotine machete injection set into the ground, located at the rear of the equipment. The furrowing rods, fixed to the equipment, were spaced $0.35 \mathrm{~m}$ apart, and the depth at which the injection was performed varied from 0.08 to $0.10 \mathrm{~m}$. The nitrification inhibitor dicyandiamide (DCD) was used, in the pure form and at a dose of $10.0 \mathrm{~kg} \mathrm{ha}^{-1}$, mixed with LSM just before the application on the soil.

After the LSM application, four soil subsamples were collected in each plot, in the $0-10 \mathrm{~cm}$ layer, to evaluate the levels of mineral $\mathrm{N}$ in the ammoniacal
$\left(\mathrm{N}-\mathrm{NH}_{4}^{+}\right)$and nitric $\left(\mathrm{N}-\mathrm{NO}_{3}^{-}\right)$forms. This procedure of sample collection was adopted due to the high variability in the levels of mineral $\mathrm{N}$ of the soil, especially soon after the application of the LSM, as verified by Morvan et al. (1996). In treatments where LSM was injected into the soil, the soil samples were collected separately in the injection furrows and between the furrows, totaling two sets of four subsamples per plot, which were analyzed separately to compose an average value. The determination of moisture and mineral $\mathrm{N}$ in the soil were carried out according to Tedesco et al. (1995), while the soil density was determined using the volumetric ring method (Embrapa 1997), obtaining a density of $1.35 \mathrm{~g} \mathrm{~cm}^{-3}$.

The soil sample collections, in the $0-10 \mathrm{~cm}$ layer, started one day after the application of the treatments and followed on the 3rd, 8th, 17th, 24th, 28th, 34th, 46th, 59th, 76th and 93rd days after their application for the 1st year, and 3rd, 7th, 15th, 24th, 34th, 45th, 51st, 64th, 83rd and 100th days in the 2nd year. The variability in the collection days was due to the fact that the study sought to monitor the variations in the levels of mineral $\mathrm{N}\left(\mathrm{N}-\mathrm{NH}_{4}^{+}\right.$and $\left.\mathrm{N}-\mathrm{NO}_{3}{ }^{-}\right)$ in the soil after the main events of pluviometric

Table 1. Main characteristics of the liquid swine manure (LSM) and applied amounts of dry matter (DM) and nitrogen (N) in the corn crop.

\begin{tabular}{|c|c|c|c|c|c|c|c|c|}
\hline \multirow[b]{2}{*}{ Crop year } & \multirow[b]{2}{*}{$\begin{array}{l}\text { Dose } \\
\mathrm{m}^{3} \mathrm{ha}^{-1}\end{array}$} & \multicolumn{4}{|c|}{ LSM characteristics } & \multicolumn{3}{|c|}{ Applied amount } \\
\hline & & $\mathrm{DM}^{(1)}$ & $\begin{array}{c}\mathrm{TN}^{(2)} \\
-\mathrm{kg} \mathrm{m}^{-3} \\
\end{array}$ & $\operatorname{Nam}^{(2)}$ & $\mathrm{pH}$ & $\mathrm{DM}$ & $\begin{array}{c}\mathrm{TN} \\
-\mathrm{kg} \mathrm{ha}^{-1} \\
\end{array}$ & Nam \\
\hline $2014 / 2015$ & 75 & 16.0 & 2.23 & 1.47 & 7.63 & $1,200.0$ & 167.25 & 110.3 \\
\hline 2016 & 46 & 14.2 & 2.37 & 2.11 & 7.83 & 653.2 & 109.02 & 97.1 \\
\hline
\end{tabular}

* TN: total N; Nam: ammoniacal N; ${ }^{(1)}$ dry base; ${ }^{(2)}$ humid base. 
precipitation. The amounts of mineral $\mathrm{N}$ found in the soil were expressed as $\mathrm{kg} \mathrm{ha}^{-1}$, with the values of recovered $\mathrm{N}$ obtained by the difference between the mineral $\mathrm{N}$ found in the treatments with the use of LSM minus the mineral $\mathrm{N}$ found in the control treatment.

The corn harvest was carried out manually on April 16, 2015 and June 06, 2016, just after the plants reached their physiological maturity. In the crop harvest, the following variables were evaluated: number of rows per ear, number of grains per row, 1,000 -grain mass and grain yield. The evaluations were carried out on ears harvested within the useful area, with the number of rows per ear and number of grains per row components being determined by direct counting on the ears, the 1,000-grain mass according to the method proposed by Brasil (2009) and the grain yield from the manual threshing of the grains, with the humidity being corrected to $13 \%$ and the value extrapolated to $\mathrm{kg} \mathrm{ha}^{-1}$.

The results were subjected to analysis of variance and, when a significant difference was observed between the treatments, the Scott-Knott test for multiple comparison of averages at $5 \%$ of probability was performed, using the Sisvar software (Ferreira 2014).

\section{RESULTS AND DISCUSSION}

After the application of the treatments, an increase was observed in the content of mineral $\mathrm{N}$ of the soil. The $\mathrm{N}-\mathrm{NH}_{4}^{+}$content recovered in the treatment with LSM injection, one day after the application, surpassed in at least $10 \mathrm{~kg} \mathrm{ha}^{-1}$ that observed with the surface application, and the positive balance of the injection persisted until 24 days after the application in the 2014/2015 crop (Figure 2a) and until the end of the evaluated period in 2016 (Figure 2b). Regarding the $\mathrm{N}^{-\mathrm{NO}_{3}}{ }_{3}^{-}$contents, a similarity was observed between the surface and injected applications, except for the evaluations conducted at 17 and 24 days after the application in 2014/2015. In these moments, the amount of $\mathrm{N}-\mathrm{NO}_{3}{ }^{-}$with the surface application surpassed the one observed with LSM injection (Figures $2 \mathrm{c}$ and $2 \mathrm{~d})$. Due to the transformation rates from $\mathrm{N}-\mathrm{NH}_{4}{ }_{4}$ to $\mathrm{N}^{-\mathrm{NO}_{3}}$, only after an average of 15 days from the LSM application the predominance of $\mathrm{N}^{-\mathrm{NO}_{3}}{ }_{3}^{-}$in the soil begins (Giacomini et al. 2013).

In the sum $\mathrm{N}-\mathrm{NH}_{4}^{+}+\mathrm{N}_{-} \mathrm{NO}_{3}^{-}$, a difference was noticed only for 2016 . The values observed with the
LSM injection were higher than the ones observed in the surface application during the entire evaluated period (Figures 2e and 2f). Furthermore, when cover fertilization was applied, values lower than those for mineral fertilization were observed in the treatment with LSM injection.

The recovery of a small fraction of the ammoniacal N, one day after applied, from the LSM is in line with what was observed by Rochette et al. (2009). According to these authors, this occurs due to the fixation of part of the $\mathrm{N}_{-} \mathrm{NH}_{4}^{+}$in the colloidal fraction of the soil and, also, by the straw retention of a fraction of the liquid part of the LSM, a fraction where the greatest proportion of the ammoniacal $\mathrm{N}$ is concentrated. This may explain the greater recovered content with the LSM injection, in relation to the surface application, in 2016.

Considering the potential of the LSM injection in reducing the $\mathrm{N}$ losses by $\mathrm{NH}_{3}$ volatilization, lower $\mathrm{N}$ contents were expected with the surface application also in $2014 / 2015$. This is because, besides the ammoniacal $\mathrm{N}$ that is present, the high initial $\mathrm{pH}$ of the LSM (Table 1) contributes to the increase of the $\mathrm{pH}$ at the soil/LSM interface, what may enhance greater $\mathrm{NH}_{3}$ emissions in the first 24 hours after the LSM application, especially when it is applied on the surface.

In addition, the elevated temperature and the obstruction of the soil pores by the particulate organic fraction may have potentiated the losses by $\mathrm{NH}_{3}$ volatilization with the surface application (Meade et al. 2011). With the LSM injection, the decrease in $\mathrm{NH}_{3}$ volatilization rates occurs due to the reduction of the $\mathrm{NH}_{3}$ concentration at the soil/atmosphere interface, as well as the greater infiltration and nitrification of the applied $\mathrm{N}-\mathrm{NH}_{4}^{+}$, resulting in a greater $\mathrm{N}$ recovering (Monaco et al. 2012).

Similarly, when urea was cover applied, a series of reactions caused the formation of ammonium, bicarbonate and hydroxyl, implying on the increase of the $\mathrm{pH}$ around the granules (Rochette et al. 2009). In this process, part of the $\mathrm{NH}_{4}^{+}$is converted to $\mathrm{NH}_{3}$ which may have been lost to the atmosphere (Rochette et al. 2009). Over time, the use of LSM has an effect on the chemical, physical and biological attributes, promoting an increase in the organic matter content of the soil, consequently resulting in an increase in the cation exchange capacity and in the retention or storage capacity of these cations (Chantigny et al. 2014), which reduces $\mathrm{N}$ losses. 

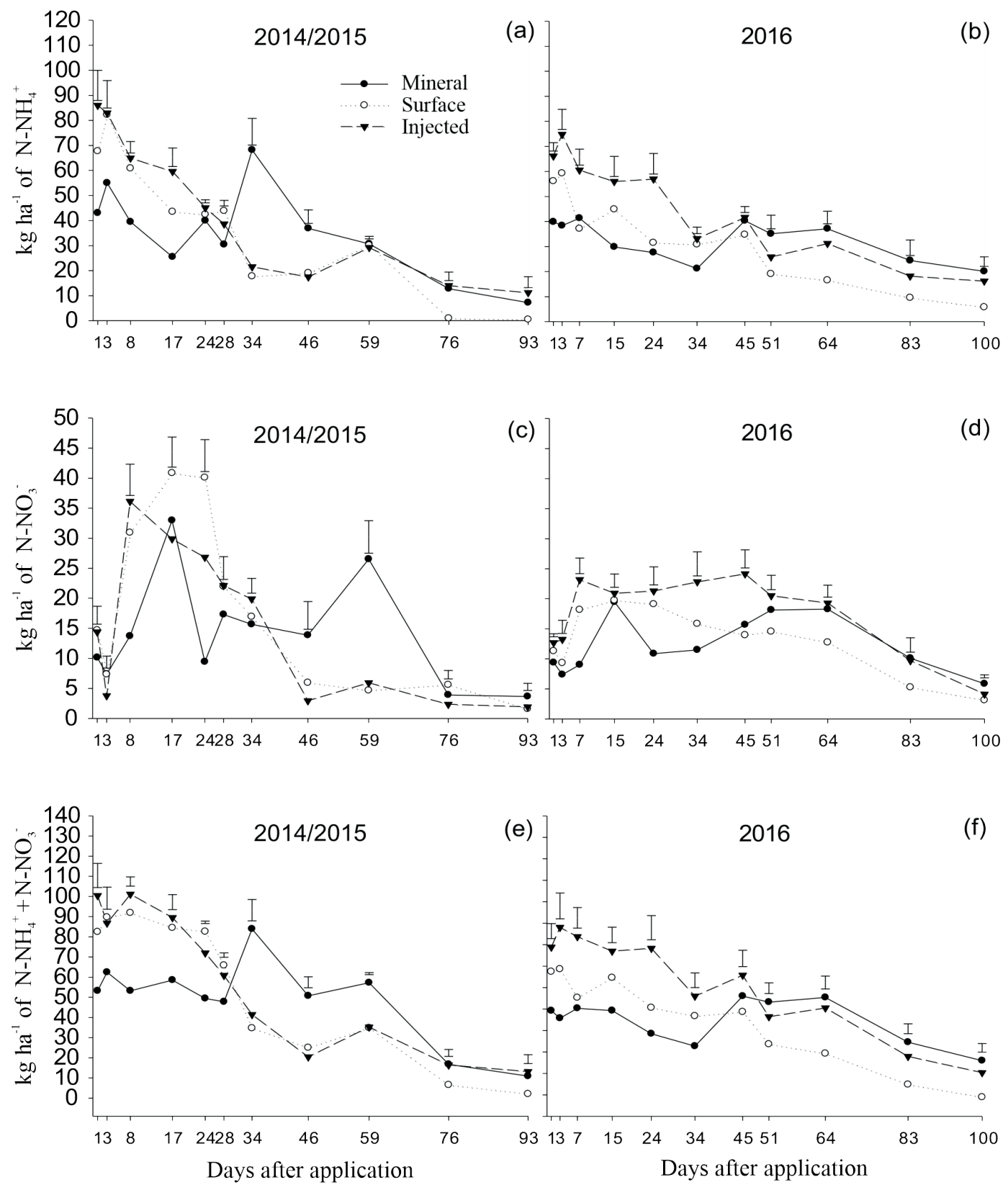

Figure 2. Mineral nitrogen $(\mathrm{N})$ on the soil in the ammoniacal form $\left(\mathrm{N}_{-} \mathrm{NH}_{4}^{+}\right)$(a and b), nitric $\left(\mathrm{N}_{-} \mathrm{NO}_{3}^{-}\right)$form (c and d) and $\mathrm{N}-\mathrm{NH}_{4}^{+}+\mathrm{N}_{-} \mathrm{NO}_{3}^{-}$(e and $\mathrm{f}$ ), as a function of the mineral fertilization and application methods (surface or injected) of the liquid swine manure. The vertical bars indicate the significant minimum difference between the averages of the treatments (Scott-Knott at 0.05).

In addition, the immobilization of the inorganic $\mathrm{N}$ of the LSM with the injection is favored, being more intense from 30 days after sowing (Morvan et al. 1996). The DCD effect may be observed by comparing the ammoniacal and nitric $\mathrm{N}$ contents on the soil.

With the LSM surface application without $\mathrm{DCD}$, and on the evaluation of the mineral $\mathrm{N}$ contents at 33 days after sowing (moment in which the definition of the productive potential of the crop

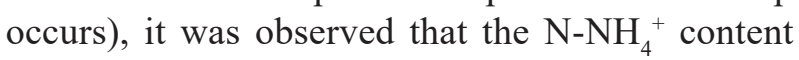
(Figures $3 \mathrm{a}$ and $3 \mathrm{~b}$ ) was reduced in $73.85 \%$ and $33.97 \%$, while, in this same time period, the $\mathrm{N}^{-\mathrm{NO}_{3}}{ }_{3}^{-}$ values (Figures 3c and 3d) increased in $15.4 \%$ and $40.3 \%$, respectively for $2014 / 2015$ and 2016 .

For the surface application with DCD, the recovered values of $\mathrm{N}^{-\mathrm{NH}_{4}}{ }^{+}$decreased $52.7 \%$ and 

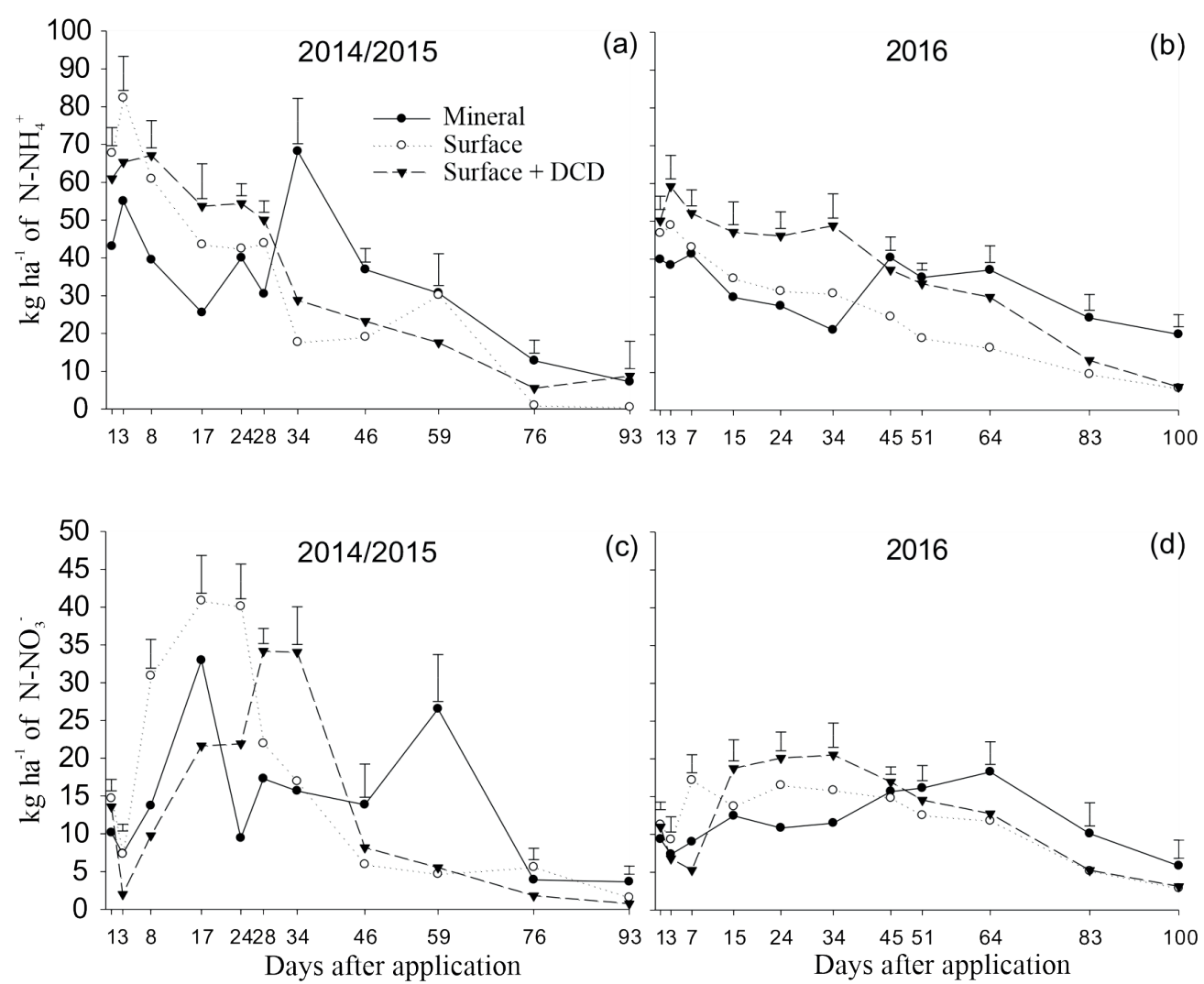

Figure 3. Mineral nitrogen $(\mathrm{N})$ on the soil in the ammoniacal $\left(\mathrm{N}_{-} \mathrm{NH}_{4}^{+}\right)$(a and b) and nitric $\left(\mathrm{N}_{-} \mathrm{NO}_{3}^{-}\right)$(c and d) forms, as a function of the mineral fertilization and surface application of the liquid swine manure without (surface) and with dicyandiamide nitrification inhibitor (surface + DCD). The vertical bars indicate the significant minimum difference between the averages of the treatments (Scott-Knott at 0.05).

$2.6 \%$; however, increments in the values of $\mathrm{N}^{-\mathrm{NO}_{3}}{ }_{3}^{-}$ $(150.6 \%$ in $2014 / 2015$ and $86.7 \%$ in 2016) were also observed.

With the LSM injection at 28 days after the emergence of the crop, the $\mathrm{N}_{-} \mathrm{NH}_{4}{ }^{+}$contents (Figures $4 \mathrm{a}$ and $4 \mathrm{~b}$ ) were reduced in $75.0 \%$ and $49.8 \%$, while, in this same time period, the values

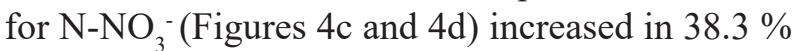
and $88.1 \%$, respectively for 2014/2015 and 2016 . For the LSM + DCD injection, the $\mathrm{N}^{-\mathrm{NH}_{4}}{ }^{+}$contents decreased $62.3 \%$ and $23.1 \%$; however, differently from what was observed with the LSM injection in the absence of DCD, the increase in the $\mathrm{N}_{-} \mathrm{NO}_{3}^{-}$ values were higher, being $133.3 \% \mathrm{ha}^{-1}$ in $2014 / 2015$ and $173.1 \%$ ha $^{-1}$ in 2016.

The change in the $\mathrm{N}$ dynamics caused by the DCD was already expected. The inhibitor would temporarily block the active site of the ammonia monooxygenase enzyme, especially in Nitrosomonas europea; thereby, the oxidation of $\mathrm{NH}_{4}^{+}$to $\mathrm{NO}_{3}^{-}$ is temporarily inhibited, reducing directly and indirectly the $\mathrm{N}$ losses and resulting in a greater content of mineral $\mathrm{N}$ on the soil (Moir et al. 2007). The difficulty in accurately evaluating the effect of the DCD through the values of $\mathrm{N}^{-N_{3}}{ }_{3}^{-}$is due to the high mobility of the anionic forms on the soil $\left(\mathrm{NO}_{2}^{-}\right.$ and $\mathrm{NO}_{3}^{-}$) and the occurrence of rain precipitation (Figure 1), where the leaching of $\mathrm{N}^{-\mathrm{NO}_{3}}{ }_{3}^{-}$to deeper soil layers than the one evaluated may have occurred.

Due to the potential that the LSM injection has in reducing the $\mathrm{N}$ losses by volatilization of $\mathrm{NH}_{3}$ (Gonzatto et al. 2016), a greater recovery of $\mathrm{N}_{-} \mathrm{NH}_{4}^{+}$ was already expected, in relation to the surface application of the manure. The $\mathrm{NH}_{3}$ volatilization is considered the main via of N loss after the LSM application, which reduces its fertilizer potential (Giacomini et al. 2013, Aita et al. 2019).

Regardless of how the application was conducted, when comparing the recovery of $\mathrm{N}^{-\mathrm{NO}_{3}}$ with or without DCD, in the presence of the inhibitor, the recovered contents at the first days after the application were lower than in its absence. For 

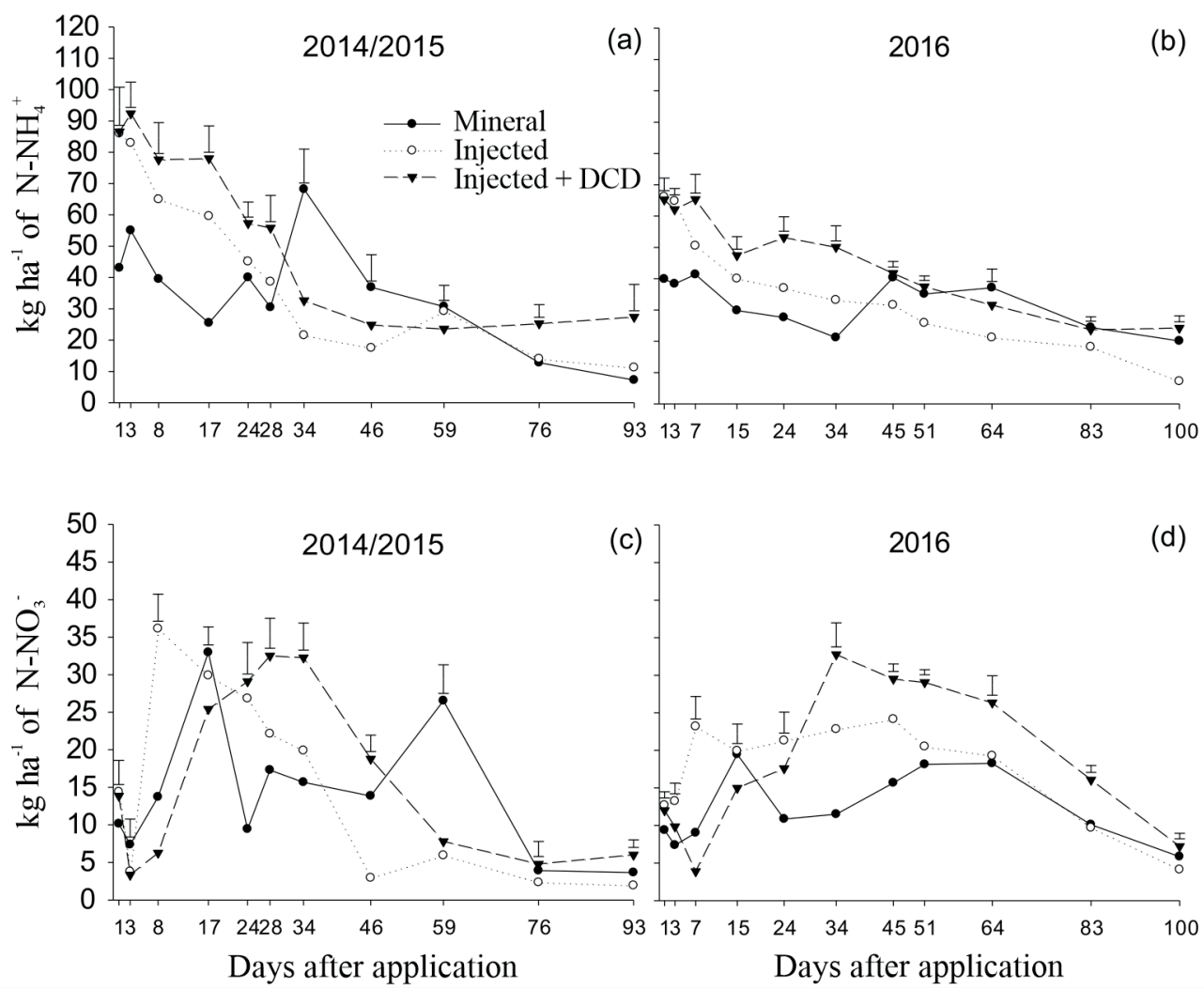

Figure 4. Mineral nitrogen $(\mathrm{N})$ on the soil in the ammoniacal $\left(\mathrm{N}-\mathrm{NH}_{4}^{+}\right)$(a and b) and nitric $\left(\mathrm{N}-\mathrm{NO}_{3}^{-}\right)$(c and d) forms, as a function of the mineral fertilization and injection of the liquid swine manure without (injected) and with dicyandiamide nitrification inhibitor (injected + DCD). The vertical bars indicate a significant minimum difference between the averages of the treatments (Scott-Knott at 0.05).

the surface application, with inhibitor, the $\mathrm{N}^{-\mathrm{NO}_{3}^{-}}$ contents were maintained lower until $27(2014 / 2015)$ and 20 (2016) days after sowing. However, with the injection, an inversion occurred on the values of $\mathrm{N}$ recovered with the use of the inhibitor after 22 and 33 days after sowing, respectively for 2014/2015 and 2016.

With the fast nitrification observed for the treatments without DCD, the emergence of $\mathrm{N}^{-\mathrm{NO}_{3}}{ }_{3}^{-}$ on the soil occurred with a speed higher than its absorption capacity by plants and microorganisms on the soil. In this condition, Giacomini et al. (2013) justified that, under rain, the leaching of anionic forms $\left(\mathrm{NO}_{2}^{-}\right.$and $\left.\mathrm{NO}_{3}^{-}\right)$prevailed, thus reducing the $\mathrm{N}$ availability.

The application of the treatments changed the number of ears $\mathrm{ha}^{-1}$, whereas an increase in the number of rows ear ${ }^{-1}$ was observed due to the LSM + DCD injection, in relation to the other treatments (Figure 5a). This probably happened due to the amount of $\mathrm{N}$ recovered on the soil at 33 days after sowing (Figure 4), when the plants were at the V4 development stage (Zadoks et al. 1974). It is at this moment that the greatest demand for $\mathrm{N}$ by plants begins, what occurs due to the differentiation in the number of ovules at the beginning of the ear formation (Carmo et al. 2012).

The greatest number of grains row $^{-1}$ was observed for the LSM+DCD injection (Figure 5b), with no difference, in relation to the mineral fertilization. In 2014/2015, the difference observed for number of rows ear ${ }^{-1}$ in the absence of DCD is associated with the greatest $\mathrm{N}$ losses in this treatment (Crusciol et al. 2011).

The high water volume precipitated between the 15th and 25th day after sowing (Figure 1) may have favored the $\mathrm{N}^{-\mathrm{NO}_{3}}{ }_{3}^{-}$leaching to regions of the soil with a low root coverage, resulting in a reduction of the nutrient availability, mainly when LSM was injected without DCD. As the number of grains row ${ }^{-1}$ is defined from the stage V8, persisting until V12, the greatest $\mathrm{N}$ availability on the soil resulting from 

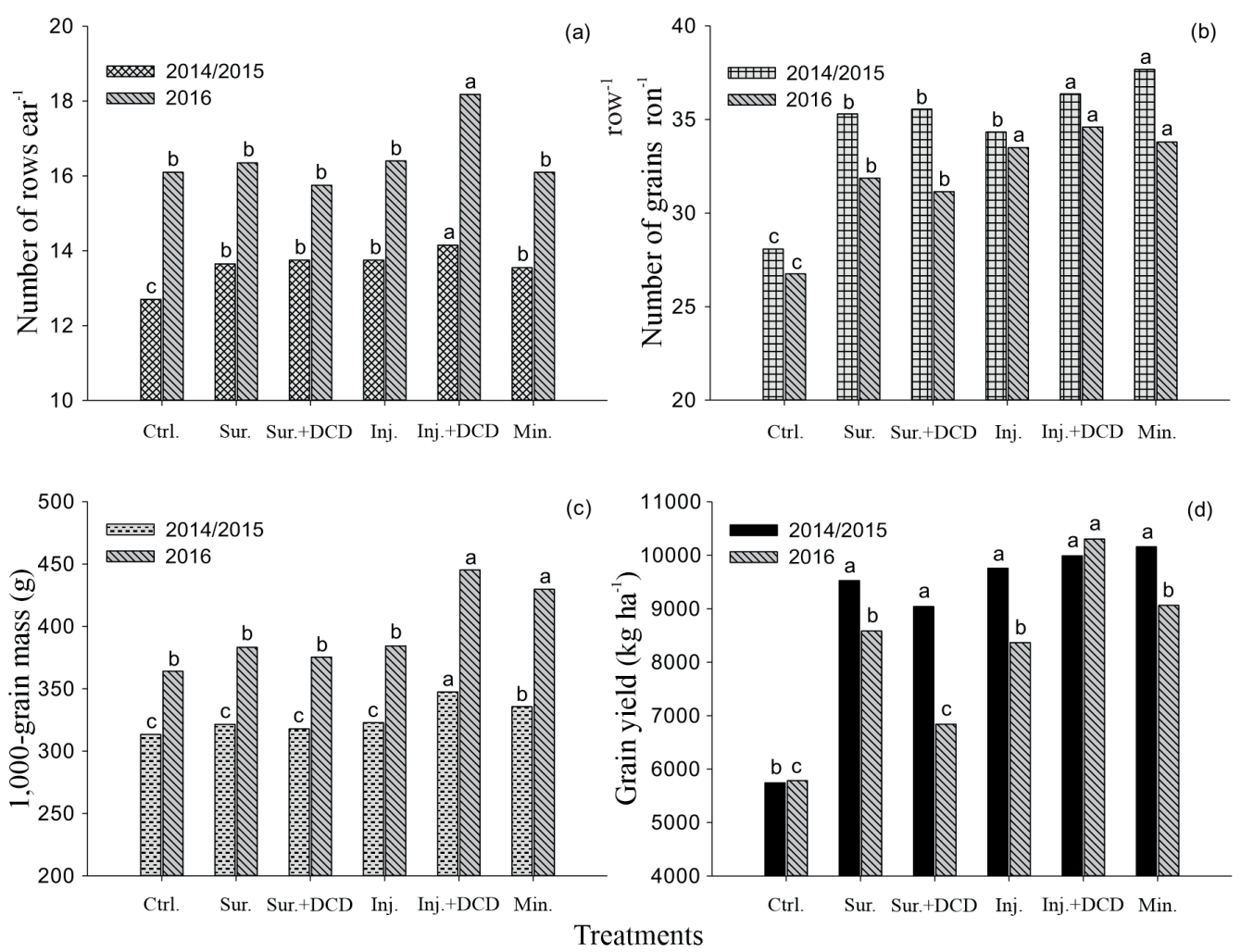

Figure 5. Corn number of rows ear ${ }^{-1}$ (a), number of grains $\operatorname{row}^{-1}(\mathrm{~b}), 1,000$-grain mass (c) and grain yield (d), as a function of the application method of liquid swine manure, presence or absence of nitrification inhibitor and mineral fertilization. Ctrl: control; Sur.: surface (total area); DCD: dicyandiamide; Inj.: injection; Min.: mineral.

the nitrification delay by DCD enabled the plants to define a greater number of grains ear ${ }^{-1}$ with the LSM injection (Carmo et al. 2012).

With increases of $3.8 \%$ (1st year) and $10.5 \%$ (2nd year), in relation to the surface application with DCD, and $6.6 \%$ and $15.2 \%$, in relation to the control, the LSM + DCD injection showed the greatest value for 1,000-grain mass, not differing from the mineral fertilization in 2016 (Figure 5c). The greatest N availability maintained the photosynthetic activity for a longer period, resulting in a greater accumulation of reserves in the grains.

As an important component of grain yield, the 1,000 -grain mass is a valuable parameter, since it is possible to obtain, from the same number of fertilized ovules, a greater yield only with the increase of the accumulated reserves in the grains (Soratto et al. 2012).

The grain yield in 2014/2015 showed no difference between the LSM application methods or the presence of $\mathrm{DCD}$, in relation to the mineral fertilization (Figure 5d), with these differences being observed only for the control treatment, which resulted in the lowest yields. In 2016, the surface application with DCD, similarly to that observed in the control treatment, showed a lower yield than the others. This result occurred due to the change in the transformation kinetics of the ammoniacal $\mathrm{N}$ to the nitric form (Figure 3), which predisposed the $\mathrm{N}-\mathrm{NH}_{4}^{+}$that was on the soil surface to volatilize in the form of $\mathrm{NH}_{3}$, reducing the fertilizing potential of the LSM (Aita et al. 2014). The greatest grain yield was observed when the LSM was injected on the soil in the presence of DCD (Figure 5d). For this treatment, it was observed a productive increase of $9.5 \%$ (1st year) and $33.6 \%$ (2nd year), in relation to the surface application with DCD, and $42.4 \%$ and $43.8 \%$, in relation to the control.

These results observed with the LSM + DCD injection are related to the greatest recovery of mineral $\mathrm{N}$ on the soil during the period of differentiation of the reproductive meristem (Carmo et al. 2012). In addition, processes linked to microbial immobilization of inorganic $\mathrm{N}$ and mineralization of organic $\mathrm{N}$ applied in 2014 may also have influenced the release of $\mathrm{N}$ into the crop in the second year, 
resulting in the greatest yield (Giacomini et al. 2013). In addition, yield is related to the ability of plants to accumulate and transfer carbohydrates through the differentiation of the reproductive system, grain formation and filling (Magalhães et al. 1997).

\section{CONCLUSIONS}

1. The injection of swine liquid manure into the soil increases its mineral nitrogen content, if compared to surface application;

2. The use of dicyandiamide reduces the transformation rate of mineral $\mathrm{N}$ in the soil to anionic forms;

3. The injection of liquid swine manure with the use of dicyandiamide does not differ from the mineral fertilization, when it comes to corn grain yield.

\section{ACKNOWLEDGMENTS}

The present study was supported by the Coordenação de Aperfeiçoamento de Pessoal de Nível Superior (Capes, Ministério da Educação, Brasil).

\section{REFERENCES}

AITA, C.; CHANTIGNY, M. H.; GONZATTO, R.; MIOLA, E. C. C.; ROCHETTE, P.; PUJOL, S. B.; SANTOS, D. B.; GIACOMINI, D. A.; GIACOMINI, S. J. Winter-season gaseous nitrogen emissions in subtropical climate: impacts of pig slurry injection and nitrification inhibitor. Journal of Environmental Quality, v. 48, n. 5, p. 1414-1426, 2019.

AITA, C.; GONZATTO, R.; MIOLA, E. C. C.; SANTOS, D. B.; ROCHETTE, P.; ANGERS, D. A.; CHANTIGNY, M. H.; PUJOL, S. B.; GIACOMINI, D. A.; GIACOMINI, S. J. Injection of dicyandiamide-treated pig slurry reduced ammonia volatilization without enhancing soil nitrous oxide emissions from no-till corn in southern Brazil. Journal of Environmental Quality, v. 43, n. 3, p. 789-800, 2014.

AITA, C.; SCHIRMANN, J.; PUJOL, S. B.; GIACOMINI, S. J.; ROCHETTE, P.; ANGERS, D. A.; CHANTIGNY, M. H.; GONZATTO, R.; GIACOMINI, D. A.; DONEDA, A. Reducing nitrous oxide emissions from a maize-wheat sequence by decreasing soil nitrate concentration: effects of split application of pig slurry and dicyandiamide. European Journal of Soil Science, v. 66, n. 2, p. 359-368, 2015.

ALVARES, C. A.; STAPE, J. L.; SENTELHAS, P. C.; GONÇALVES, J. L. de M.; SPAROVEK, G. Köppen's climate classification map for Brazil. Meteorologische Zeitschrift, v. 22, n. 6, p. 711-728, 2013.

ANGERS, D. A.; CHANTIGNY, M. H.; MACDONALD, J. D.; ROCHETTE, P.; COTE, D. Differential retention of carbon, nitrogen and phosphorus in grassland soil profiles with long-term manure application. Nutrient Cycling in Agroecosystems, v. 86, n. 2, p. 225-229, 2010.

BRASIL. Ministério da Agricultura, Pecuária e Abastecimento. Regras para análise de sementes. Brasília, DF: MAPA/ACS, 2009.

CARMO, M. S.; CRUZ, S. C. S.; SOUZA, E. J. de; CAMPOS, L. F. C.; MACHADO, C. G. Doses e fontes de nitrogênio no desenvolvimento e produtividade da cultura de milho doce (Zea mays convar. saccharata var. rugosa). Bioscience Journal, v. 28, n. 1, p. 223-231, 2012.

CERETTA, C. A.; BASSO, C. J.; VIEIRA, F. C. B.; HERBES, M. G.; MOREIRA, I. C. L.; BERWANGER, A. L. Dejeto líquido de suínos: I - perdas de nitrogênio e fósforo na solução escoada na superfície do solo, sob plantio direto. Ciência Rural, v. 35, n. 6, p. 1296-1304, 2005.

CERETTA, C. A.; GIROTTO, E.; LOURENZI, C. R.; TRENTIN, G.; VIEIRA, R. C. B.; BRUNETTO, G. Nutrient transfer by runoff under no tillage in a soil treated with successive applications of pig slurry. Agriculture, Ecosystems and Environment, v. 139, n. 4, p. 689-699, 2010.

CHANTIGNY, M. H.; HARRISON-KIRK, T.; CURTIN, D.; BEARE, M. Temperature and duration of extraction affect the biochemical composition of soil waterextractable. Soil Biology and Biochemistry, v. 75, n. 1, p. 161-166, 2014.

COMISSÃO DE QUÍMICA E FERTILIDADE DE SOLO (CQFS). Manual de adubação e calagem para os estados do Rio Grande do Sul e Santa Catarina. 10. ed. Porto Alegre: Sociedade Brasileira de Ciência do Solo, 2004.

CRUSCIOL, C. A. C.; GARCIA, R. A.; CASTRO, G. S. A.; ROSOLEM, C. A. Nitrate role in basic cation leaching under no-till. Revista Brasileira de Ciência do Solo, v. 35, n. 6, p. 1975-1984, 2011.

DELL, C. J.; KLEINMAN, P. J.; SCHMIDT, J. P.; BEEGLE, D. B. Low-disturbance manure incorporation effects on ammonia and nitrate loss. Journal of Environmental Quality, v. 41, n. 3, p. 928-937, 2012.

EMPRESA BRASILEIRA DE PESQUISA AGROPECUÁRIA (Embrapa). Manual de métodos de análises de solo. 2. ed. Rio de Janeiro: Embrapa, 1997.

EMPRESA BRASILEIRA DE PESQUISA AGROPECUÁRIA (Embrapa). Sistema brasileiro de classificação de solos. 3. ed. Brasília, DF: Embrapa, 2013. 
FERREIRA, D. F. Sisvar: a guide for its bootstrap procedures in multiple comparisons. Ciência \& Agrotecnologia, v. 38, n. 2, p. 109-112, 2014.

GIACOMINI, S. J.; AITA, C.; PUJOL, S. B.; MIOLA, E. C. C. Transformações do nitrogênio no solo após adição de dejeto líquido e cama sobreposta de suínos. Pesquisa Agropecuária Brasileira, v. 48, n. 2, p. 211-219, 2013.

GONZATTO, R.; AITA, C.; BÉLANGER, G.; CHANTIGNY, M. H.; MIOLA, E. C. C.; PUJOL, S. B.; DESSBESEL, A.; GIACOMINI, S. J. Response of no-till grain crops to pig slurry application methods and a nitrification inhibitor. Agronomy Journal, v. 109, n. 4, p. 1-10, 2017.

GONZATTO, R.; CHANTIGNY, M. H.; AITA, C.; GIACOMINI, S. J.; ROCHETTE, P.; ANGERS, D. A.; PUJOL, S. B.; ZIRBES, E.; BASTIANI, G. G.; LÜDKE, R. C. Injection and nitrification inhibitor improve the recovery of pig slurry ammonium nitrogen in grain crops in Brazil. Agronomy Journal, v. 108, n. 3, p. $978-988,2016$.

MEADE, G.; PIERCE, K.; O'DOHERTY, J. V.; MUELLER, C.; LANIGAN, G.; MCCABE, T. Ammonia and nitrous oxide emissions following land application of high and low nitrogen pig manures to winter wheat at three growth stages. Agriculture, Ecosystems and Environment, v. 140, n. 1-2, p. 208-217, 2011.

MAGALHÃES, P. C.; DURÃES, F. O. M.; GOMIDE, R. L. Fisiologia da cultura do milho. Sete Lagoas: Embrapa Milho e Sorgo, 1997.

MOIR, J. L.; CAMERON, K. C.; DI, H. J. Effects of the nitrification inhibitor dicyandiamide on soil mineral $\mathrm{N}$, pasture yield, nutrient uptake and pasture quality in a grazed pasture system. Soil Use and Management, v. 23, n. 2, p. 111-120, 2007.

MONACO, S.; SACCO, D.; PELISSETTI, S.; DINUCCIO, E.; BALSARI, P.; ROSTAMI, M.; GRIGNANI, C. Laboratory assessment of ammonia emission after soil application of treated and untreated manures. Journal of Agricultural Science, v. 150, n. 1, p. 65-73, 2012.
MORVAN, T.; LETERME, P.; MARY, B. Quantification des flux d'azote consécutifs à un épandage de lisier de porc sur triticale en automne par marquage isotopique ${ }^{15} \mathrm{~N}$. Agronomie, v. 16, n. 9, p. 541-552, 1996.

OLIVEIRA, L. V.; HIGARASHI, M. M.; NICOLOSO, R. S.; COLDEBELLA, A. Use of dicyandiamide to reduce nitrogen loss and nitrous oxide emission during mechanically turned co-composting of swine slurry with sawdust. Waste and Biomass Valorization, v. 11, n. 1, p. 2567-2579, 2020.

ROCHETTE, P.; ANGERS, D.; CHANTINI, M. H.; MACDONALD, J. D.; GASSER, M.; BERTRAND, $\mathrm{N}$. Reducing ammonia volatilization in a no-till soil by incorporating urea and pig slurry in shallow bands. Nutrient Cycling in Agroecosystems, v. 84, n. 1, p. 71-80, 2009.

SEIDEL, E. P.; GONÇALVES JUNIOR, A. C.; VANIN, J. P.; STREY, L.; SCHWANTES, D.; NACKE, H. Aplicação de dejetos de suínos na cultura do milho cultivado em sistema de plantio direto. Acta Scientiarum: Technology, v. 32, n. 2, p. 113-117, 2010.

SORATTO, R. P.; COSTA, T. A. M. da; FERNANDES, A. M.; PEREIRA, M.; MARUYYAMA, W. I. Parcelamento de fontes alternativas de nitrogênio no milho safrinha em sucessão à soja. Cientifica, v. 40, n. 2, p. 179-188, 2012.

TEDESCO, M. J.; GIANELLO, C.; BISSANI, C. A.; BOHNEN, H.; VOLKWEISS, S. J. Análise de solo, plantas e outros materiais. 2. ed. Porto Alegre: Ed. UFRGS, 1995.

VALLEJO, A.; GARCIA-TORRES, L.; DÍEZ, J. A.; ARCE, A.; LÓPES-FERNÁNDEZ, S. Comparison of N losses $\left(\mathrm{NO}_{3}^{-}, \mathrm{N}_{2} \mathrm{O}, \mathrm{NO}\right)$ from surface applied, injected or amended (DCD) pig slurry of an irrigated soil in a Mediterranean climate. Plant and Soil, v. 272, n. 1, p. 313325, 2005.

ZADOKS, J. C.; CHANG, T. T.; KONZAC, C. F. A decimal code for the growth stages of cereals. Weed Research, v. 14, n. 6, p. 415-421, 1974. 